\title{
IMMIGRATION AND RACIAL INEQUALITY. THE ITALIAN CASE
}

\author{
Fabio Perocco \\ Ca' Foscari University of Venice \\ Venice, Italy \\ fabio.perocco@unive.it
}

\begin{abstract}
The aim of the article is to show how in Italy the traditional inequalities in class, gender and geography have been matched by an inequality linked to immigration, whose causes, forms and social consequences I will analyse here. In so doing I will underline how such inequality linked to immigration is an integral part of the system of social inequalities existing at global level and in particular it is part of the globalization of inequality linked to immigration.

Over the last few decades, there has been a deep social transformation at world level which has changed the system of inequalities; new inequalities were created, among which, the inequality linked to immigration is rather important. Historically, this is certainly nothing new, yet we are witnessing a globalization of inequality linked to immigration, which refers to disparities and social advantages that affect immigrant populations and citizens with migratory background. This phenomenon has several causes, but it is mainly due to two elements: the systematic use by several countries of an exploited and stigmatised migrant workforce, kept in a condition of social inferiority and with half the rights of the rest of the population; the globalisation of selective, restrictive and repressive immigration policies.

Such process is quite visible in Italy, where inequality based on immigration is the result of the combined action of labour market, legal system, and mass media, which have pursued rationales, which led to the social inferiority and segregation of immigrants. Such inequality involved specific generative
\end{abstract}


mechanisms such as the selection, precarisation and differential exploitation of migrant workers, the creation of a special legislation, the systematic stigmatisation of immigrant populations in the public discourse, the comeback of the rhetoric of assimilation. Such inequality is multidimensional as, from work to health, from living to education, from public images to legal conditions, it affects all aspects of the social life of immigrants; and it is a challenge to social citizenship.

\section{Keywords}

Globalisation, immigration, inequalities, racism.

\section{INTRODUCTION}

Over the last few decades, there has been a deep and unrestrained process of social transformation at world level, in the wake of neo-liberalism. Such global restructuring - which took place in a slow and fragmented way in the $80^{\prime} \mathrm{s}$, and in a more organic and faster way in the 90's and 2000's - is a unitary process that has worked at global level and, from the macro to the micro domain, it has restructured economies, work organisation, the structures and shapes of states, daily lives, social rights and the system of inequalities.

Old international inequalities have undergone a radical rearrangement: in what may seem a contradiction, on one hand inequalities between countries have been relatively mitigated in a number of cases (after the recovery of some countries of the South of the world and the inclusion of the BRICS in the world market), on the other hand they have been harshened in terms of global inequalities and inequalities within countries (Alvaredo et al. 2018; Milanovic 2005, 2016; Therborn 2006). The aggravation of social polarisation within each country is a truly global phenomenon, and it is not an exaggeration to talk about the globalisation of social polarisation within countries. It took place in different ways and degrees according to the geographical context and, with a very few exceptions, it roughly presented two phases: an acceleration from the early $80^{\prime} \mathrm{s}$ to the mid-2000, and a super-acceleration with the great crisis of 2008. The 
economic crisis has broadened and deepened, but not created, such process, from which a sort of global apartheid seemed to emerge.

At the same time, new inequalities formed - adding up to the old ones without replacing them - among which, a noteworthy one is inequality linked to immigration, inequality by nationality linked to migration, to the fact of having migrated to a foreign country. Inequality based on immigration can be defined using a concept historically used in the USA and in the UK - a racial inequality or ethno-racial inequality and it refers to disparities and social advantages that affect immigrant populations and citizens with migratory background ${ }^{1}$, refers to inequalities (in the field of income, wealth, housing, health, education, rights, etc.) between majority and migrant nationality groups, between national workers and migrant workers within a country.

Historically, inequality linked to immigration is certainly nothing new (Potts 1990; Sayad 1999), on the contrary, yet today we are living a fully-fledged globalisation of inequality based to be an immigrant, linked to immigration. In the wake of the formation of the world market and world labour market, on the basis of the globalization of industrial processes and market economy, in Europe, USA, Japan, but also in the Middle East, in South America, in Asia, a large part of the immigrant populations lives a condition of inequality (at economic, juridical, and symbolic level) compared to the autochthonous populations. This phenomenon, I repeat, is not new, but compared to the past, today it is much more widespread and presents itself as a unitary process. It has several causes, which vary according to national contexts, but it is mainly due to three common elements: 1) the systematic use by several countries of an exploited and stigmatised migrant workforce, kept in a condition of social inferiority and with half the rights of the rest of the population, to lower the cost of labour and compete on global markets; 2) the globalisation of selective, restrictive and

1 See Bonilla-Silva (2003), Novick (1995), Solomos (2003). Everyone knows that races do not exist, but on the social level, on the level of social relations, they exist and are more alive than ever; very often in Europe migrants are considered as inferior races (even if they have a white skin) or - using common terms - inferior cultures, inferior peoples, inferior ethnicities (Basso 2016). 
repressive migration policies, with States and governments competing in the harshening of condition of migration and worsening of immigrants' conditions; 3) the convergence of processes of work casualisation and precarisation of migration on immigrant workers, that live a condition of double precarity.

A noteworthy example of the process of creation of an inequality linked to immigration from Global South is Italy, where the latter added up to class, gender, generation and geographical inequalities, traditionally established.

The aim of this article is to show how in Italy the traditional inequalities have been matched by an inequality linked to immigration, whose causes, forms and social consequences I will analyse here. In so doing I will underline how such racial inequality linked to immigration is an integral part of the system of social inequalities existing at global level and in particular it is part of the globalization of inequality linked to immigration.

Such new inequality in Italy is the result of a discrimination system affecting structurally all aspects of immigrants' life and of the social relationships between the Italian society and immigrant populations; in particular, it is the result of the combined action of at least three structures of social stratification - the labour market, the legal system, the mass-media - that have pursued rationales which led to social inferiority and segregation. Such inequality, affecting immigrant populations in different ways, has seen the application of specific generative mechanisms such as the selection, the precarisation and differential exploitation of immigrant workers, the creation of a special legislation, the systematic stigmatisation in the public discourse, the comeback of the rhetoric of assimilation. Such inequality is multidimensional as, from work to health, from living to education, from public images to legal conditions, it affects all aspects of the social life of immigrants (Saraceno et al. 2013).

Before delving into the analysis, it should be underlined that the original deep cause of this inequality lies in "ordinary racism" within the Italian society (Balbo and Manconi 1990), especially in the unstoppable rise of institutional racism that has taken place over the last fifteen years, which has entailed a thorough racialisation of social relations (Basso 2010). 


\section{RACISM AND INEQUALITY AT WORK.}

In Italy, immigrants' work is marked across the table - from access to work to unemployment, from tasks to remuneration, from professional status to mobility, from work accidents to social security - by inequalities, compared with national workers (Fullin and Reyneri 2011; Idos 2016; Moressa 2012).

Immigrant workers - around 2,400,000 people, i.e. $10 \%$ of the total employed workers - suffer a significant work segregation concentrating them mainly in low-skilled manual jobs (Moressa 2014, 44). The majority is employed in the lower segments of the labour market, in low-paying and low-skilled jobs, more tiresome and unhealthier, such as construction worker, farm labourer and janitor, domestic help and caregiver, in the sectors of low-skilled services (to companies, to families), hotels and restaurants, metal and tanning industries, textiles and construction, seasonal agriculture and agri-food. In 1999, 77.3\% were qualified general workers and labourers (Fieri-Ilo 2003), while in 2012 were still $87.1 \%$ compared to $39.6 \%$ of the national workers (Moressa 2012, 33). In the last years the increase in immigrant workers has always taken place almost completely within low-skilled jobs, thus consolidating the channelling and ethno-racial segmentation of the labour market; in 2016, more than two thirds were qualified general workers and labourers (Unar 2016, 255-263).

Immigrant workers are often under-classified, and for a longer period compared to national workers. Over-education - i.e. having a job requiring a lower set of skills compared to the education obtained - affects $40.9 \%$ immigrant workers and $21.6 \%$ national workers (Idos 2016, 262); employment under-classification, i.e. having an employment contract corresponding to a lower level compared to the tasks carried out, is very common among migrant workers, with negative consequences on wages. In the construction sector, where the presence of immigrant workers is quite noteworthy, in 2008 only $4 \%$ were classified as 4 th level skilled worker, whereas the majority was classified as labourer and ordinary worker (Galossi and Mora 2008); in 2013, 55\% of them worked as ordinary worker compared to $28 \%$ of national workers, 4 th level and skilled workers were only $13 \%$ of immigrants compared to $36.5 \%$ of national workers (Fillea-Cgil 2013). 
Over education and under-classification of immigrant workers are constantly fed by several factors, among which two stand out: the continuous relapse in underground economy and administrative irregularity, following work precarity and permanent under-employment; and the increase in immigrant workers in the low-skilled services sector, mainly due to the growth in female employment as houseworkers and caregivers, and the shift of a remarkable number of male workers coming from factory work. The economic crisis has enlarged and amplified the over education and under-classification of immigrant workers as, in the context of high unemployment and harshening of migration policies, in order to find or keep a job enabling them to obtain or renew their residence permit, immigrants are forced to accept a lower classification, relinquishing career growth or the expectation to see their qualifications acknowledged.

The majority of immigrant women is employed in housework, care work, services, as domestic help, caregivers, cleaners, waitresses. In these sectors they easily find a job - given the increase in the demand of services identified as "female work", migratory chains and the functioning of niche economies - but at the same time they are cages outside of which employment opportunities are very limited. The average monthly wage of immigrant women is very low (822 euro); work segmentation based on gender and nationality, together with their concentration in low level services, is mirrored in a significant wage difference, both compared to immigrant men (1,122 euro) and Italian women (1,202 euro) (Idos 2016, 262), confirming the three-fold oppression affecting immigrant women (because women, workers, foreigners; Anthias 1992; Morokvasic 1983). As for houseworkers and caregivers (a little over a million, a part of which works without a contract), they undergo, globally, a situation of work segregation, with tough consequences on their material and life conditions.

Immigrant workers are affected by a higher unemployment $(16.2 \%$ vs $11.4 \%$ among national workers) and under-employment rate $(11.7 \%$ vs $4.2 \%)$ and by a wide contract precarity that lasts longer than national workers (Idos 2016, 262). When the economic crisis hit, immigrant and national workers were both affected by unemployment and under-employment, yet the former suffered the hardest situation due to their penalisation in firing provisions and in enjoying social safety nets. 
A good portion of the unemployed has found a new job, completely or partly irregular, thus enlarging the underground economy, a structural element of the Italian economy and a source of attraction of undocumented migration. The entry (or relapse) in the underground economy has entailed a worsening of the working conditions - from wages to hours, from tasks to safety - and a lower protection from discrimination in the workplace. In such permanent circulation between administrative and contract regularity and irregularity, the deterioration of working conditions and the weakening of their position on the labour market have taken place.

These elements, associated to working conditions which are not improving with length of service, to a marked presence in jobs with little career opportunities and little wage raises linked to the length of service, take their toll on wages, which are lower than those of national workers (mean net monthly wage: $979 €$ vs $1362 €$ ) (Idos 2016, 255-262). Such wage differences are also linked to the size of the company and the working sector: among immigrants, more than among locals, employment mainly takes place in small-sized companies, where there are higher chances of worse working conditions.

Such wages place immigrant workers and their families in the lower-paid income layers of Italian society. Together with young precarious couples, single mothers, people over 50 years of age expelled early from the labour market, immigrant workers and their families are an important component of the worse-off social layers. The creation of this lower layer of very-low income workers and poor immigrant families (in 2015 immigrant families had, on average, an income corresponding to two-thirds the income of Italian families: $19,725 €$ vs $30,320 €$; Istat 2015), has taken place simultaneously with processes of decline in wages, multiplication of the working poor, social polarisation, shrinking of the middle class, which have affected the Italian society over the past two decades. Though a fair share of the hard conditions of immigrant families may be comparable to those of many Italian families which are poor, impoverished or at risk of poverty, the economic crisis affected immigrant families the hardest, also considering that earned income and subsidies for income support (unemployment, family allowances) are the main source of income of immigrant families, while, unlike for locals, earnings deriving from land, pensions and buildings (19\% of 
immigrant families are home-owners, compared to $80 \%$ of Italian families) are quite negligible (Unar 2016; Istat 2017).

The condition of immigrant workers presents specific critical situations on the access to work, task distribution, or mobility. The majority of them reaches higher qualifications and wages very slowly, also because they are employed in jobs offering fewer career opportunities; often career development is linked to migration seniority, but itself is more than sometimes a barrier as the labour market, especially in low-skilled jobs, presents a drive towards the replacement of "old" and rooted immigrant workers with new and recently arrived migrants. Horizontal mobility is more widespread, but it does not always entail an improvement of the working conditions, and especially it does not involve all sectors as some jobs (housework or care work, for instance) mean the workers' fate is sealed once they start performing such tasks.

Access to work, the distribution of tasks, the role in the production process are all included in a permanent process of national, "racial" and ethno-religious selection, on two levels. On one hand, for a number of jobs and tasks, national workers are preferred over immigrant workers, and to justify the choice the usual chauvinist arguments are used, on skills, attitudes, vocations, availability or mentality of the former (rappresented as good, loyal, bright, efficient and diligent workers) and the latter (rappresented as lazy, disobedient, stupid, slow and troublemaker workers). On the other hand, there is a permanent selection of immigrant workers which, according to an alleged natural inclination or cultural vocation (be them positive or negative), includes and excludes specific populations and marginalizes earlier-immigrated workers, more rooted and demanding, by replacing them with recently-arrived migrants, less rooted and less stable. In specific sectors such as agriculture or construction, for instance, Maghreb workers have slowly been ousted, as they were more organized and unionised, and have been replaced with Eastern-European workers, in the context of the replacement of non-EU workers with workers from new EU members - who do not require a residence permit - hired irregularly without the risk of being accused of facilitation of illegal immigration. Finally, based on national stereotypes and false myths, often specific national groups are linked to specific jobs, specific parts of the production process, so much so that it is not 
rare to witness the ethnicisation of production processes, confining single national groups to specific steps of the production.

Such inequality at work, affecting the majority of immigrants, is the permanent drive of the racial inequality existing in Italy and is closely matched by a marked inequality in rights. The legislation and migration policy, as we shall see, have placed immigrants in a special legal system marked by half the rights and targeted unfavourable provisions (Bartoli 2008; Basso 2010; Morozzo Della Rocca 2008).

\section{ANTI- IMMIGRANTS POLICIES BETWEEN PRECARISATION AND CRIMINALISATION}

Until 1990, when law No. 39 on the placement of immigrant workers was published, the main reference was the "Consolidated law on public security", of 1931, which equalled the presence of foreigners to that of an enemy in a control and security point of view, and such stance influenced the legislation on immigration of the following decades.

In the meantime, the legal framework, extremely poor compared to the new situation, has been integrated over the years with the publication of several administrative circular letters which have been considered the main legal basis; indeed, the first regularisation was carried out by means of an administrative circular letter, as was the introduction of the residence permit. Secondary rank norms, internal provisions within ministries and public administration which are not sources of law, administrative circular letters do not provide a general political orientation and in their application leave great room for interpretation, discretion and arbitrariness; yet, such room has entailed a process of "administratisation of migration policies" (Gjergji 2013a, 2013b), still prevalent today especially in the field of asylum seekers.

After this legal vacuum, law No. 39, expressing a closure towards immigration, set up a migration policy which institutionalised undocumented immigration and the social inferiority of immigrants, and which lay the foundations of the 
provisions that followed. This law introduced a quota mechanism for immigrant workers with the creation of a three-year or yearly "inflow decree" which sets out the number of entries permitted for work, yet, in the first few years it was not passed or it established zero entries possible, while in the following years it established very low numbers, forcing, as a result, the majority of immigrants to embrace irregular work and undocumented migration. As for the tools to manage inflows, this law established - together with administrative expulsion the recruitment by name mechanism, which sets forth, as a condition to enter the Italian territory, the presence of a work contract deriving from the prior encounter in the country of origin between the worker and the employer. This mechanism turned out to be rather inadequate for a productive system as the Italian one, marked by small-medium enterprises, a growth in the poor services sector and underground economy, but it enabled the processes of illegalisation of migration and growth of underground economy.

This law, accompanied by a third regularisation, established that the bureaucracy to authorize the entry shall be started by the employer, a principle enshrined in the following laws on immigration, as the foundation of migration policies: law No. 189/2002 provides that the employer shall be the only subject who may require the work permit for the immigrant worker and having the possibility and subjective right to apply for a residence permit - the immigrant worker does not have such possibility and is not considered a subject of law, but rather the object of legal acts and other people's rights.

These key points of law No. 39, continued and strengthened by the laws that followed, had very negative results on the working and social lives of immigrants, forced to live as undocumented migrants waiting for a regularisation or an inflow decree (which is a regularisation under cover as it legalises those who are already in Italy) to obtain documents and become "legal". The majority of immigrants has had and still has to go through a rough road, with a slow outflow from forced illegality and a transition towards regular work, where each step achieved corresponds to obtaining a segment of rights and fragments of social rights.

Law No. 40, of 1998, considering immigration a structural element of the Italian society and presented as comprehensive legislation, included important chapters 
on social and cultural aspects, yet its overall design resulted in the configuration of immigrants as bound to the socially-defined role of "subordinate" and in the institutionalisation of two categories of immigrants, "legal" and "illegal", with differences as regards their rights.

It introduced a bond between residence permit, work and dwelling, thus institutionalising the insertion model based on undocumented migration and social precarity, developed over the previous years, and binding the exercise of social rights to the migratory status. In line with law No. 39, it put down on paper the existing social practices, confirming that for immigrant workers "illegal" migration is a staging post, that their regularisation can only take place afterwards and at the discretion of their employer, thus creating a relationship of strong dependence of the worker from the employer. It facilitated the fact that an immigrant with a residence permit may relapse into undocumented or underdocumented migration if he is not able to keep his prerequisites for renewal; furthermore, with the guaranteed quota system and recruitment by name it subordinated legal entries to the needs of the labour market in the short term.

Besides the creation of temporary detention centres, following the fragmentation of the types of residence permit and the multiplication of their durations, it produced a stratification of the legal status of immigrants, which led to the creation of several categories with different rights. Such difference lies at the base of the hierarchy of precarity and of the civic stratification among immigrant populations.

In the 2000's, migration policies were characterised by a two-fold process of precarisation and criminalisation of immigrants, in particular with the application of selective, restrictive and punitive politics (Basso 2010). Law No. $189 / 2002$, represented by the political slogan "zero immigration", based on the new restrictive definition of the prerequisites for residence with the introduction of the "residence contract", produced in reality a zero-rights immigration, extremely liable to be blackmailed, hanging on a thread, willing to do anything to avoid a relapse into undocumented immigration. It is based on the concept that residence must be strictly subordinated to the employment, the existence of an employment contract, the only element making the legality of the residence 
legitimate, in a perspective of thorough jus laboris. Such design, materialised in the creation of a strict bond between work, residence permit and dwelling, turned out to be a powerful drive for the institutional production of mass clandestinity; this law, which stated it wanted to counter undocumented migration, actually created it, to then criminalize it - so much so that a good portion of the immigrants detained in prisons are there for breaking the law on immigration, an administrative offense.

The numerous negative provisions of this law (the elimination of the "sponsor"; the reduction of the maximum validity of residence permits - maximum two years; the reduction of the maximum length of unemployment - six months; the increase in the maximum term of detention in temporary detention centres from thirty to sixty days) determined a contraction of the rights of immigrants, the majority of which live in conditions of considerable precarity by law, increased by the interaction with the norms on liberalisation of the labour market. It reduced the number of legal entry channels and exacerbated the instability of residence, with the actual and permanent risk of a relapse into clandestinity; it determined a considerable dependence by the immigrant worker on the employer and subordinated the exercise of social rights to the validity of the work contract; it intensified the security aspects, making a stricter repression against undocumented migrants; it cleared the right of asylum from its effectiveness. Hence, it gave new momentum and orientation to the process of creation of a special legislation for immigrants, which afterwards found new systematisation and codification in law No. 94/2009 ("Provisions on public safety"). Law no. 189 formalized what previous laws, administrative circulars, the practices of the public administration, had produced over the previous decades, thus establishing the existence of a condition of legal, political and social inferiority for immigrants.

Over this period, Italian migration policy picked up the German and Swiss experience of the Gastarbeiter, linking the duration of the residence permit to the duration of the employment contract. The maximum duration of the residence permit was reduced, inflows for seasonal work were promoted (to respond to the demand of just-in-time workforce by sectors marked by seasonality and to discourage the stabilisation of immigrant populations), family reunification was 
hindered by raising the level of prerequisites, favouring individual immigration, for very mobile and barely rooted people. Yet, the return of the Gastarbeiter has taken place within a flexible capitalism - with its context of fragmentation, polarization and precarity - and in a situation of economic stagnation. Torn between a condition of rigidity determined by the norms on immigration and a condition of flexibility determined by the norms on the labour market, immigrants ended up being guest-workers in a period of economic crisis, rise of unemployment, growth of precarity, and weakening of the labour movement.

In the last decade migration policies were further harshened and have taken on a markedly racial connotation; a plethora of punitive provisions by central and local administrations produced considerable institutional discrimination and inequality in rights. Striking examples are local resolutions and national norms against the poor, which linked access to residence in the municipality to a set income; the "ethnic" census of the Roma people; the limitations in the possibilities of family reunification; the tax on the residence permit; the extension of detention in the Centres for Identification and Expulsion up to six months; the impossibility for undocumented immigrants to obtain authorizations, certificates and administrative measures, among which social benefits; the reporting obligation to the police of undocumented immigrants for doctors, teachers and civil servants; the aggravating circumstance of clandestinity in case of crimes committed by undocumented immigrants: this measure, entailing an increase by a third of the sanction when the offense is perpetrated by an undocumented immigrant, in June 2010 was rejected by the Constitutional Court (sentence 08/07/2010 n. 2491; Masera 2010) on grounds of unconstitutionality as it does not target an illicit behaviour, but rather a condition, a status, the subjective condition of undocumented.

All this placed immigration in a situation of social clandestinity, of total precarity of the very existence of immigrants, symbolised by the creation of the residence

1 See the sentence available on the site of Italian Constitutional Court: Https:/ / www.cortecostituzionale.it/actionSchedaPronuncia.do?anno=2010\&numero=249 \#. 
permit with a point system, articulated in credits, obtained during the validity of the permit itself (a sort of game of chutes and ladders).

This was accompanied by the return of assimilationism which, as in other European countries, further marked Italian migration policies according to the maximum adaptation of immigrants to the conditions imposed to them (work, housing, etc.). The anti-immigrants offensive on the legislation and propaganda plans - useful to keep under more pressure and control migrant work, more easily - supported migration policies characterized by a mixture of identity and security elements, aimed at discouraging social integration of immigrants and at supporting temporary fluctuating migrations, thus sustaining the demand of just-in-time workforce (Gjergji 2016). The new Gastarbeiter is forced to embrace the values of the receiving society and to be assimilated in the national culture, even though their presence is provisional and temporary. Migration policies, several social forces, opinion campaigns, public speeches, and thousands of local administration measures designed for immigrants a path marked by temporariness and assimilation, impermanence and forced embrace of national culture.

The focus on security and repression of the Italian migration policies of the past few years was further confirmed by the provisions applied in the field of asylum seekers, which were enshrined in law No. 46/2017 - converting decree-law No. 13 of 17 February 2017 "Urgent provisions to accelerate procedures on international protection". This decree, born together with the decree-law on the security of cities (No. 14 of 20 February 2017), introduces a generalization of the Hotspot approach of the new European migration policy ${ }^{1}$, which entails several procedural and substantial changes. It entails the amendment to the first instance judgment of international protection, i.e. the replacement of "summary orders" with chamber proceedings without a hearing, thus eliminating the open public aspect of the proceedings, the oral cross-examination and the possibility for the judge to ask questions to the asylum seeker who lodged an appeal; it entails the

1 The hotspot approach is one of the pillars of the European Agenda on Migration 2015 and it based on the large-scale implementation of asylum-seekers and refugees centres. See https:/ /ec.europa.eu/home-affairs/.../2_hotspots_en.pdf (15.07.2017). 
elimination, in cases for international protection, of the second instance judgment for asylum seekers appealing against a rejection (quite an exception in the field of subjective rights, protected by the Italian Constitution); it establishes special sections for asylum applications and repatriations in Courts of Appeal; it widens the network of Detention centers for undocumented migrants, which change their name from "Centres of Identification and Expulsion" into "Centres for repatriations" (in view of increasing the rate of rejections and expulsions); in case of notifications to be delivered to the asylum seeker, it entails the extension of the qualification as Public official to the person in charge of the Center or of the hosting structure; finally, it introduces voluntary community service work (as an expression of goodwill towards integration and as a sort of compensation for the state and the receiving society) (Pasqualetto 2017). Finally, in 2018 there was a marked harshening of migration policies, which ended up in state shipwrecks, in state deaths in the Mediterranean Sea. Such harshening, turned into the main feature of the national politics, has been feeding popular racism, leading to a manhunt on immigrants, Roma and asylum seekers.

\section{THE MASS MEDIA INDUSTRY OF STIGMATISATION}

The creation of a symbolic system of stigmatisation of immigration has supported and justified the material exploitation and the social inferiorisation of immigrants. Such symbolic inequality has had material consequences, feeding the production and reproduction of inequality. The most important social actor of this stigmatisation process was the system of mass-media, which presented immigration as a special reality, which needs special measures.

In the '80s and '90s the public image of immigrants was associated to poverty, misery, marginality, but also to a far, primitive world (Belluati, Grossi and Viglongo 1995; Cotesta 1999; Iris 1991). The image of immigrants was that of the "pickaninny" from colonial postcards, belonging to an inferior humanity, poorly talented and evolved, fresh off the tree, who needed the help of civilized people to live. This image has its main sources in anti-African racism, of colonial origin, from which the discourse on the inferiority of non-white races and non-European 
cultures was taken (Burgio 1999; Basso 2016); this is also a source of rhetoric, symbols, imagery, exoticism, paternalism, all adjusted to the new context to describe immigration in Italy.

In the following years, the public image of immigrants has undergone a sudden, two-fold change. On one hand, it has become more negative, following a process of denigration carried out by the mass-media, which presented immigrants as a global threat (Binotto and Martino 2004; Binotto, Bruno and Lai 2016; Censis 2002; Dal Lago 2009; Sibhatu 2004); on the other hand, it has greatly diversified, articulated in a heterogeneous complex of images according to nationality, culture of origin, social condition, etc. From generic terms such as "vu' cumprà" (mimicking the way African street vendors would say "vuoi comprare?", i.e. "would you like to buy?") or "marocchino" ("Moroccan", used for all migrants), through which immigrants were identified and devalued, a set of more "sophisticated" inferiorising stereotypes (the invader, the drug dealer, the profiteer, the idler, the criminal, etc.) was developed, based on a mechanism of selective racism, which identified "good communities" and "bad communities", "desirable" and "undesirable immigrants". Functional to the differential exploitation of immigrants, this selective mechanism was directed, from time to time, against immigrant populations that most massively entered the labour market, which were more stable, organized and rooted, i.e. against those populations that had increased their social centrality. First the Moroccans, then the Albanians, the Nigerians, the Chinese, the Romanians, were targeted by specific denigration campaigns, with the application of an anti-Arab, antiAfrican, anti-Chinese racism, each with its own rhetoric and its own system of negative images.

Turned into a fully-fledged media industry of contempt, the mass-media system has created a regime of racialised representation of the Italian society, useful to the subordinate insertion of immigrants, who have suffered constant categorizations, always revisited according to the circumstances (be them international, national or local), or to the different social groups affected. The differentiation of the public images of immigrants has targeted, according to the circumstances or the political situation, one population or the other, one social component or the other, creating different categories, identified as unusual, 
dangerous, despicable, disgusting or gruesome. At the bottom of such hierarchy, based on the rhetoric and on the routine discourse (Maneri 2001, 2002) focused on social alarm and emergency, on opposites such as compatibility/incompatibility, reliability/unreliability, we find "undocumented immigrants", "the Roma" and "the Muslim"; "the Albanian criminal", "the Moroccan drug dealer", "the deadbeat refugees", "immigrant women: servants or prostitutes", "the Chinese mafia", "the second generation", "the unaccompanied foreign minors", "the foreign pupil who is too loud".

Last, but not least, over the 2000's, the mass-media system has taken on a major role in the relationship between receiving society and immigrant populations, by carrying out a crucial function in backing, supporting, justifying and requesting exclusion policies and punitive measures. It has fed the process of racialisation of social relations, developed over time in the Italian society; it has demanded, supported and justified policies and interventions that international institutions clearly defined as discriminatory; it backed the discourse placing on immigrants the responsibility of the social issues (turned into an "ethnic issue"); it favoured the development of two separate societies or the presence of a caste of untouchables within the Italian society.

\section{CONCLUSIONS}

In this article I have examined the process of development of inequality linked to immigration, of a racial inequality based on immigration, in Italy today. This process is part of the general social processes evolved in the last few decades, especially in the global transformations which have taken place in the wake of neoliberal globalization, which highlighted old inequalities and created new ones. Migration is not a self-standing phenomenon, a "world of its own", it is an integral part of the functioning of the social system and thus, inequality linked to immigration is a structural element both of the system of inequalities existing at global and national level, and of the process of creation of the world labour market (with all its stratifications) to which international migrations belong. In such global phenomena, social rights and social citizenship are even more 
linked and subordinated to nationality. For immigrant workers, social rights in their receiving countries are largely tied to their migratory status in the State. Civic stratification, as a system of inequality (Morris 2002; Amaya-Castro 2017), justifies and fosters the idea of unequal, segmented rights based on nationality. To tackle inequality linked to immigration in so many countries in the world, a global social citizenship is at least necessary, going beyond the visible and invisible borders of national states and overcoming the "global inequalities/national social citizenship" aporia. Global social citizenship challenges this unequal segmentation, it may not an absolute solution, but it certainly is a progressive protective factor.

\section{REFERENCES}

- Alvaredo, Facundo et all. 2018. World Inequality Report 2018, https:/ / wir2018.wid.world (accessed 11 June 2018).

- Amaya-Castro, Juan. 2017. "In its Majestic Inequality". Migration Control and Differentiated Citizenship", in Jürgen Mackert and Bryan Turner (eds). The Transformation of Citizenship vol. 2, London, Routledge, 2017, p. 84-100.

- Anthias, Floya. 1992. Ethnicity, class, gender and migration. Avebury: Aldershot.

- Balbo, Laura and Luigi Manconi. 1990. I razzismi possibili. Milan: Feltrinelli.

- Bartoli, Clelia. 2008. Razzisti per legge. Rome-Bari: Laterza.

- Basso, Pietro (ed.). 2010. Razzismo di stato. Stati Uniti, Europa, Italia: Milan: Franco Angeli.

- Basso, Pietro. 2016. Le racisme européen. Paris: Syllepse.

- Belluati, Marinella, Grossi Giorgio and Eleonora Viglongo. 1995. Mass-media e società multietnica. Milan: Anabasi.

- Binotto, Marco and Valentina Martino. 2004. FuoriLuogo. Cosenza: PellegriniRai Eri.

- Binotto, Marco, Bruno Marco and Valeria Lai. 2016. Tracciare confini. L'immigrazione nei media italiani. Milan: Franco Angeli.

- Bonilla-Silva, Eduardo. 2003. Racism without Racists. Color-blind Racism and the Persistence of Racial Inequality in the United States. Lanham: Rowman $\mathcal{E}$ Littlefield. 
- Burgio, Alberto (ed.) 1999. Nel nome della razza. Bologna: Il Mulino.

- Censis. 2002. L'immagine degli immigrati e delle minoranze etniche nei media. Rome: Censis.

- Cotesta, Vittorio. 1999. "Semantica della differenza etnica. Globalizzazione e immagini dell'Altro nei mass media italiani (1991-1995)". Sociologia urbana e rurale 59: 9-31.

- Dal Lago, Alessandro. 2009. Non persons. The exclusion of migrants in a global society. Milan: Ipoc.

- Fierillo. 2003. La discriminazione dei lavoratori immigrati nel mercato del lavoro in Italia. Geneva: Ilo.

- Fillea-Cgil. 2013. IX Rapporto sui lavoratori stranieri nelle settore delle costruzioni. Rome: Fillea-Cgil.

- Fondazione Moressa. 2012. Rapporto annuale sull'economia dell'immigrazione 2012. Bologne: Il Mulino.

- Fondazione Moressa. 2014. Rapporto annuale sull'economia dell'immigrazione 2014. Bologne: Il Mulino.

- Fullin, Giovanna and Emilio Reyneri. 2001. "Low unemployment and bad jobs for new immigrants in Italy", International Migration 49 (1): 118-147.

- Galossi, Emanuele and Maria Mora. 2008. I lavoratori stranieri nel settore edile. Rome: Fillea-Cgil.

- Gjergji, Iside. 2013. "L'infra-droits des étrangers: le gouvernement par circulaires et la gestion administrative des mouvements migratoires en Italie". Migrations Société 147-148: 53-68.

- Gjergji, Iside. 2013. Circolari amministrative e immigrazione. Milan: Franco Angeli.

- Gjergii, Iside. 2016. Sulla governance delle migrazioni. Milan : Franco Angeli.

- Iris. 1991. Lo straniero di carta. Rimini: Il Ponte.

- Istat. 2015. Reddito e condizioni di vita. Rome: Istat.

- Istat. 2017. Annuario statistico 2017. Rome: Istat.

- Maneri, Marcello. 2001. Les médias dans le processus de construction sociale de la criminalité des immigrés. Le cas italien, in Salvatore Palidda (coord.), Délit d'immigration, Bruxelles, COST-CE, 2007, p. 51-72.

- Maneri, Marcello. 2002. Lo straniero consensuale, in Alessandro Dal Lago (coord.), Lo straniero e il nemico, Genoa, Costa \& Nolan, 2002, p. 236-272.

- Masera, Luca. 2010. "Costituzionale il reato di clandestinità, incostituzionale l'aggravante: le ragioni della Corte costituzionale". Diritto, Immigrazione e Cittadinanza, 3: 37-58. 
- Milanovic, Branko. 2005. Worlds Apart. Princeton: Princeton University Press.

- Milanovic, Branko. 2016. Global Inequality. Harvard: Harvard University Press.

- Morokvasic, Mirjana. 1983. Women in migration: beyond the reductionist outlook, in Annie Phizacklea (ed.), One-Way Ticket. Migration and female labor, London, Routledge, p. 13-31.

- Morozzo Della Rocca, Paolo. 2008. Immigrazione e cittadinanza. Turin: Utet.

- Morris, Lydia. 2002. Managing Migration. Civic Stratification and Migrants Rights. London: Routledge.

- Novick, Michael. 1995. White Lies, White Power. Monroe: Common Courage Press.

- Pasqualetto, Martina. 2017. "Il 'volontariato' dei richiedenti asilo in Italia". Remhu 25 (49): 233-248.

- Potts, Lydia. 1990. The World Labour Market. A History of Migration. London: Zed Books.

- Saraceno, Chiara, Sartor Nicola and Giuseppe Sciortino (eds). 2013. Stranieri e disuguali. Bologne: Il Mulino.

- Sayad, Abdelmalek. 1999. La double absence. Paris: Seuil.

- Sibhatu, Ribka. 2004. Il cittadino che non c'è. Rome: Edup.

- Solomos, John. 2003. Race and Racism in Britain. London: Palgrave Macmillan.

- Therborn, Göran. 2006. Inequalities of the World. London-New York: Verso.

- Unar. 2016. Dossier statistico immigrazione 2016. Rome: Idos. 